\title{
Ruthenium cluster chemistry: Monodentate bis(diphenylphosphino)acetylene-ligated cluster modules in chain and dendrimer formation
}

\author{
Lydie Viau ${ }^{\mathrm{a}}$, Anthony C. Willis ${ }^{\mathrm{b}}$, Mark G. Humphrey ${ }^{\mathrm{a}, *}$ \\ ${ }^{a}$ Department of Chemistry, Australian National University, Canberra, ACT 0200, Australia \\ ${ }^{\mathrm{b}}$ Research School of Chemistry, Australian National University, Canberra, ACT 0200, Australia
}

Received 21 December 2006; received in revised form 18 January 2007; accepted 18 January 2007 Available online 25 January 2007

\begin{abstract}
Reaction of $\mathrm{Ru}_{3}(\mu-\mathrm{dppm})(\mathrm{CO})_{10} \quad[\mathrm{dppm}=\operatorname{bis}(\mathrm{diphenylphosphino)methane}]$ with one equivalent of dppa [dppa $=$ bis(diphenylphosphino)acetylene] afforded $\mathrm{Ru}_{3}(\mu-\mathrm{dppm})(\mathrm{CO})_{9}\left(\eta^{1}\right.$-dppa) which possesses a monodentate dppa ligand, an X-ray structural study revealing that all phosphorus donor atoms are arranged in equatorial coordination sites with respect to the triruthenium cluster plane. Reaction of $\mathrm{Ru}_{3}(\mathrm{CO})_{9}(\mathrm{NCMe})_{3}$ with excess dppa afforded fair yields of $\mathrm{Ru}_{3}(\mathrm{CO})_{9}\left(\eta^{1} \text {-dppa }\right)_{3}$, which possesses three monodentate dppa ligands. Reaction of three equivalents of $\mathrm{Ru}_{3}(\mu-\mathrm{dppm})(\mathrm{CO})_{9}\left(\eta^{1}-\mathrm{dppa}\right)$ with $\mathrm{Ru}_{3}(\mathrm{CO})_{9}(\mathrm{NCMe})_{3}$ or reaction of $\mathrm{Ru}_{3}(\mathrm{CO})_{9}\left(\eta^{1}-\mathrm{dppa}\right)_{3}$ with excess $\mathrm{Ru}_{3}(\mu-d p p m)(\mathrm{CO})_{10}$ afforded low yields of the dodecanuclear first-generation dendrimer $\mathrm{Ru}_{3}(\mathrm{CO})_{9}\left\{\mathrm{PPh}_{2} \mathrm{C}_{2} \mathrm{PPh}_{2} \mathrm{Ru}_{3}-\right.$ $(\mu$-dppm $\left.)(\mathrm{CO})_{9}\right\}_{3}$. Reaction of $\mathrm{WIr}_{3}(\mu-\mathrm{CO})_{3}(\mathrm{CO})_{8}\left(\eta-\mathrm{C}_{5} \mathrm{Me}_{5}\right)$ with excess $\mathrm{Ru}_{3}(\mu$-dppm $)(\mathrm{CO})_{9}\left(\eta^{1}\right.$-dppa) afforded fair yields of the decanuclear dppa-bridged tri-cluster $\mathrm{WIr}_{3}(\mathrm{CO})_{9}\left\{\mathrm{PPh}_{2} \mathrm{C}_{2} \mathrm{PPh}_{2} \mathrm{Ru}_{3}(\mu \text {-dppm })(\mathrm{CO})_{9}\right\}_{2}\left(\eta-\mathrm{C}_{5} \mathrm{Me}_{5}\right)$.
\end{abstract}

(c) 2007 Elsevier B.V. All rights reserved.

Keywords: Crystal structure; Dendrimer; Iridium; Ruthenium; Tungsten

\section{Introduction}

Transition metal cluster chemistry is well-developed [1], but most studies have focused on mono-cluster compounds. Linking clusters by various bridging groups has been of interest for at least two reasons - the properties associated with the individual mono-cluster building blocks can potentially be modified if the cluster units "communicate" with each other, and, while mono-cluster units are usually highly crystalline, clusters inserted into the backbone of an oligomer or polymer may afford film-processible materials. Diphosphines have been used to link clusters [2]. In particular, and relevant to the present studies, the rigid bidentate diphosphine bis(diphenylphosph-

\footnotetext{
${ }^{*}$ Corresponding author. Tel.: +6126125 2927; fax: +61261250760.

E-mail address: Mark.Humphrey@anu.edu.au (M.G. Humphrey).
}

ino)acetylene (dppa) has been employed in many studies to link two cluster units [3], but examples of its use in the construction of higher oligoclusters or cluster dendrimers are rare [4].

We have previously reported the synthesis of $\mathrm{Ru}_{3}$ $(\mathrm{CO})_{9}\left\{\left(\mathrm{Ph}_{2} \mathrm{PC}_{6} \mathrm{H}_{4}-4-\mathrm{C} \equiv \mathrm{C}\right) \mathrm{Ru}\left(\mathrm{PPh}_{3}\right)_{2}\left(\eta-\mathrm{C}_{5} \mathrm{H}_{5}\right)\right\}_{3}$, a cluster-centered organometallic star [5], tetrametallic group 6-group 9 mixed-metal cluster-containing oligourethanes [6], and di- and tri-cluster compounds in which the mixed-metal cluster modules are linked by a variety of potentially $\pi$-delocalizable organic bridging units [7-9]. We report herein the synthesis of $\mathrm{Ru}_{3}(\mathrm{CO})_{9}\left(\eta^{1} \text {-dppa }\right)_{3}$, which contains three monodentate dppa ligands, the single-crystal X-ray study of $\mathrm{Ru}_{3}(\mu$-dppm $)(\mathrm{CO})_{9}\left(\eta^{1}\right.$-dppa $)$, which contains one monodentate dppa ligand, and studies examining the utility of these two clusters in the construction of a tri-cluster chain and a tetra-cluster dendrimer. 


\section{Experimental}

\subsection{General conditions}

The reaction solvents $\mathrm{CH}_{2} \mathrm{Cl}_{2}$, THF, and $\mathrm{MeCN}$ were analytical reagent (AR) grade and were dried over $\mathrm{CaH}_{2}$, sodium/benzophenone, and $\mathrm{P}_{2} \mathrm{O}_{5}$, respectively, and distilled under nitrogen. Petroleum spirit refers to a fraction of boiling range $60-80^{\circ} \mathrm{C} . \mathrm{Me}_{3} \mathrm{NO}$ was freshly sublimed before use. Dppa (Aldrich) was used as received. Literature procedures (or minor modifications thereof) were used to synthesize $\mathrm{Ru}_{3}(\mu$-dppm $)(\mathrm{CO})_{10}[10,11], \mathrm{Ru}_{3}(\mathrm{CO})_{9}(\mathrm{NCMe})_{3}$ [12], $\mathrm{Ru}_{3}(\mu-\mathrm{dppm})(\mathrm{CO})_{9}\left(\eta^{1}\right.$-dppa) (1) [13], and $\mathrm{WIr}_{3^{-}}$ $(\mu-\mathrm{CO})_{3}(\mathrm{CO})_{8}\left(\eta-\mathrm{C}_{5} \mathrm{Me}_{5}\right)$ [14]. The reaction products were purified by thin-layer chromatography (TLC) on $20 \times 20 \mathrm{~cm}$ glass plates coated with Merck $\mathrm{GF}_{254}$ silica gel $(0.5 \mathrm{~mm})$.

IR spectra were recorded on a Perkin-Elmer System 2000 FT-IR with $\mathrm{CaF}_{2}$ solution cells as solutions in dichloromethane (AR grade); spectral frequencies are recorded in $\mathrm{cm}^{-1}$. The ${ }^{1} \mathrm{H}$ and ${ }^{31} \mathrm{P}$ NMR spectra were recorded in $\mathrm{CDCl}_{3}$ (Cambridge Isotope Laboratories) using a Varian Gemini-300 spectrometer at $300 \mathrm{MHz}$ or $121 \mathrm{MHz}$ and referenced to residual $\mathrm{CHCl}_{3}$ at $7.24 \mathrm{ppm}$ or external $\mathrm{H}_{3} \mathrm{PO}_{4}$ at $0.0 \mathrm{ppm}$, respectively. The following new data were obtained for previously reported compounds: $\mathrm{Ru}_{3}(\mu-\mathrm{dppm})(\mathrm{CO})_{10}:{ }^{31} \mathrm{P}$ NMR $(\delta) 14.9$ (s); $\mathrm{Ru}_{3}(\mu$-dppm)$(\mathrm{CO})_{9}\left(\eta^{1}\right.$-dppa) (1): ${ }^{31} \mathrm{P}$ NMR $(\delta) 15.8\left(\mathrm{~m}, 2 \mathrm{P}, \mathrm{Ph}_{2} \mathrm{PCH}_{2^{-}}\right.$ $\left.\mathrm{PPh}_{2}\right), 8.1\left(\mathrm{~m}, 1 \mathrm{P}, \mathrm{RuPh}_{2} \mathrm{P}\right),-30.5(\mathrm{~d}, J=6.1 \mathrm{~Hz}, 1 \mathrm{P}$, $\mathrm{Ph}_{2} \mathrm{PC} \equiv \mathrm{C}$ ). The secondary ion (SI) mass spectra were recorded using a VG Autospec instrument at the Research School of Chemistry, ANU ( $30 \mathrm{kV} \mathrm{Cs}^{+}$ions, current $1 \mathrm{~mA}$, accelerating potential $8 \mathrm{kV}$, 3-nitrobenzyl alcohol matrix, solutions in $\mathrm{CH}_{2} \mathrm{Cl}_{2}$ ). The electrospray (ES) mass spectrum was recorded on a VG Platform II spectrometer at the University of Waikato, Hamilton, New Zealand. The mobile phase was $\mathrm{MeOH}$, pumped at $0.02 \mathrm{~mL} \mathrm{~min}^{-1}$ using a Spectra Physics P1000 pump. The sample was dissolved in $\mathrm{MeOH}$ and injected into the spectrometer via a Rheodyne valve with a $10 \mathrm{~mL}$ loop. The source temperature was $60{ }^{\circ} \mathrm{C}$, and nitrogen was used as both nebulizing and drying gas. Skimmer cone voltage was maintained at a low value (typically $20 \mathrm{~V}$ ) to minimize fragmentation of ions. MS data are reported in the form: $\mathrm{m} / \mathrm{z}$ (assignment, relative intensity). Elemental microanalyses were carried out by the Microanalysis Service Unit in the Research School of Chemistry, ANU.

\subsection{Synthesis of $\mathrm{Ru}_{3}(\mathrm{CO})_{9}\left(\eta^{l}-d p p a\right)_{3}$ (2)}

$\mathrm{Ru}_{3}(\mathrm{CO})_{9}(\mathrm{NCMe})_{3}(101.8 \mathrm{mg}, 0.15 \mathrm{mmol})$ and dppa (284 mg, $0.72 \mathrm{mmol}$ ) were added to a mixture of $\mathrm{CH}_{2} \mathrm{Cl}_{2} /$ $\mathrm{MeCN}(10 \mathrm{~mL} / 5 \mathrm{~mL})$ in a Schlenk tube. A deep red solution was immediately obtained. This solution was stirred at room temperature for 4 days. The solution was taken to dryness and subjected to TLC $\left(1: 1 \mathrm{CH}_{2} \mathrm{Cl}_{2}\right.$ :petroleum spirit eluant). Four bands were obtained. The first band
$\left(R_{\mathrm{f}}=0.83\right)$ was identified as unreacted dppa $(85 \mathrm{mg})$ by ${ }^{1} \mathrm{H}$ and ${ }^{31} \mathrm{P}$ NMR. Band $2\left(R_{\mathrm{f}}=0.56\right.$, red $)$ was identified as $\mathrm{Ru}_{3}(\mathrm{CO})_{9}\left(\eta^{1}-\mathrm{dppa}\right)_{3}(\mathbf{2})(80 \mathrm{mg}, 30 \%)$. Anal. Found: C, 60.53; H, 3.88\%. $\mathrm{C}_{87} \mathrm{H}_{60} \mathrm{O}_{9} \mathrm{P}_{6} \mathrm{Ru}_{3}$ Calc.: C, 60.11; H, 3.48. IR ( $\left.v_{\mathrm{CO}}\right): 2051 \mathrm{w}, 1992 \mathrm{~s}, 1979 \mathrm{~s}, 1955 \mathrm{~m} \mathrm{~cm}^{-1}$. ${ }^{1} \mathrm{H}$ NMR $(\delta) 7.61-7.27(\mathrm{~m}, 60 \mathrm{H}, \mathrm{Ph}) .{ }^{31} \mathrm{P}$ NMR $(\delta) 7.6$ (d, $\left.J=3 \mathrm{~Hz}, 3 \mathrm{P}, \mathrm{RuPPh}_{2}\right),-30.0 \quad(\mathrm{~d}, J=3 \mathrm{~Hz}, 3 \mathrm{P}$, $\mathrm{C} \equiv \mathrm{CPPh}_{2}$ ). ES $\mathrm{MS}: 1792 \quad[\mathrm{M}+\mathrm{Na}+2 \mathrm{O}]^{+}, 33 ; 1776$ $[\mathrm{M}+\mathrm{Na}+\mathrm{O}]^{+}, 100 ; 1760[\mathrm{M}+\mathrm{Na}]^{+}, \quad 55 ; 1592[\mathrm{M}+\mathrm{Na}$ $-6 \mathrm{CO}]^{+}, 12$. The contents of the third and fourth bands ( $R_{\mathrm{f}}=0.45$ and $R_{\mathrm{f}}=0.34$, respectively) were not identified.

\subsection{Synthesis of $\mathrm{Ru}_{3}(\mathrm{CO})_{9}\left\{\mathrm{PPh}_{2} \mathrm{C}_{2} \mathrm{PPh}_{2} \mathrm{Ru} u_{3}(\mu-d p p m)\right.$ $(\mathrm{CO})_{9\}_{3}}(3)$}

Method $A . \mathrm{Ru}_{3}(\mathrm{CO})_{9}(\mathrm{NCMe})_{3}(16.8 \mathrm{mg}, 0.025 \mathrm{mmol})$ and $\quad \mathrm{Ru}_{3}(\mu-\mathrm{dppm})(\mathrm{CO})_{9}\left(\eta^{1}\right.$-dppa) (1) $\quad(105.7 \mathrm{mg}$, $0.079 \mathrm{mmol}$ ) were placed in a Schlenk tube and a mixture of $\mathrm{CH}_{2} \mathrm{Cl}_{2} / \mathrm{MeCN}(10 \mathrm{~mL} / 5 \mathrm{~mL})$ was added. The resultant red mixture was stirred at room temperature for 3 days, after which time the solution was taken to dryness and subjected to TLC (11:9 $\mathrm{CH}_{2} \mathrm{Cl}_{2}$ :petroleum spirit eluant). Three bands were obtained. The first ( $R_{\mathrm{f}}=0.68$, yellow) and second $\left(R_{\mathrm{f}}=0.57\right.$, orange) bands appeared to be in trace amounts and were not isolated. The contents of the third and major red band $\left(R_{\mathrm{f}}=0.43\right)$ were identified as $\mathrm{Ru}_{3}(\mathrm{CO})_{9}\left\{\mathrm{PPh}_{2} \mathrm{C}_{2} \mathrm{PPh}_{2} \mathrm{Ru}_{3}(\mu-\mathrm{dppm})(\mathrm{CO})_{9}\right\}_{3} \quad$ (3) $\quad$ (6.5 mg, 6\%). IR ( $\left.v_{\mathrm{CO}}\right): 2055 \mathrm{w}, 1996 \mathrm{~s}, 1980 \mathrm{~s}, 1955 \mathrm{~m} \mathrm{~cm}^{-1} \cdot{ }^{1} \mathrm{H}$ NMR $(\delta) 7.53-7.15(\mathrm{~m}, 120 \mathrm{H}, \mathrm{Ph}), 4.56\left(\mathrm{t}, J_{\mathrm{P}-\mathrm{H}}=12 \mathrm{~Hz}\right.$, $\left.6 \mathrm{H}, \mathrm{PCH}_{2} \mathrm{P}\right) .{ }^{31} \mathrm{P}$ NMR $(\delta) 16.2$ (br, 6P, $\mathrm{PPh}_{2} \mathrm{CH}_{2} \mathrm{PPh}_{2}$ ), $12.3\left(\mathrm{t}, J_{\mathrm{P}-\mathrm{P}}=10 \mathrm{~Hz}, 3 \mathrm{P}, \mathrm{Ru}_{3}(\mathrm{CO})_{9}(\mu-\mathrm{dppm}) P \mathrm{Ph}_{2}\right), 10.4$ (s, 3P, $\left.\mathrm{Ru}_{3}(\mathrm{CO})_{9} \mathrm{PPh}_{2}\right)$. SI MS: $4559[\mathrm{M}]^{+}$. This compound proved unstable in solution, precluding crystallization.

Method $B . \mathrm{Me}_{3} \mathrm{NO}$ was added to a stirred solution of $\mathrm{Ru}_{3}(\mathrm{CO})_{9}\left(\eta^{1} \text {-dppa }\right)_{3}(2)(29.7 \mathrm{mg}, 0.017 \mathrm{mmol})$ and $\mathrm{Ru}_{3^{-}}$ $(\mu \text {-dppm)(CO) })_{10}(57.8 \mathrm{mg}, 0.060 \mathrm{mmol})$ in THF $(60 \mathrm{~mL})$. The solution was stirred $24 \mathrm{~h}$ at room temperature and additional $\mathrm{Me}_{3} \mathrm{NO}(5 \mathrm{mg})$ was added. The solution was stirred for a further $3 \mathrm{~h}$ and taken to dryness. Purification as described above afforded the product as a red powder (3.3 mg, 4\%).

\subsection{Synthesis of $\mathrm{WIr}_{3}(\mathrm{CO})_{9}\left\{\mathrm{PPh}_{2} \mathrm{C}_{2} \mathrm{PPh}_{2} \mathrm{Ru}_{3}(\mu-d p p m)\right.$ $(\mathrm{CO})_{9\}_{2}}\left(\eta-\mathrm{C}_{5} \mathrm{Me}_{5}\right)(4)$}

A mixture of $\mathrm{Ru}_{3}\left(\mu\right.$-dppm) $(\mathrm{CO})_{9}\left(\eta^{1}\right.$-dppa) (1) $(45.3 \mathrm{mg}$, $0.034 \mathrm{mmol})$ and $\operatorname{WIr}_{3}(\mu-\mathrm{CO})_{3}(\mathrm{CO})_{8}\left(\eta-\mathrm{C}_{5} \mathrm{Me}_{5}\right)(12.7 \mathrm{mg}$, $0.011 \mathrm{mmol})$ in $\mathrm{CH}_{2} \mathrm{Cl}_{2}(20 \mathrm{~mL})$ was stirred for $42 \mathrm{~h}$ at room temperature. The solution was taken to dryness in vacuo and the residue taken up to a minimum of acetone. TLC (3:7 acetone:petroleum spirit eluent) afforded a number of bands. The major band $\left(R_{\mathrm{f}}=0.23\right)$ was identified as the disubstituted compound $\mathrm{WIr}_{3}(\mathrm{CO})_{9}\left\{\mathrm{PPh}_{2} \mathrm{C}_{2} \mathrm{P}-\right.$ $\left.\mathrm{Ph}_{2} \mathrm{Ru}_{3}(\mu-\mathrm{dppm})(\mathrm{CO})_{9}\right\}_{2}\left(\eta-\mathrm{C}_{5} \mathrm{Me}_{5}\right) \quad$ (4) $\quad(15 \mathrm{mg}, \quad 40 \%)$. Anal. Found: C, 43.51; H, 2.89\%. $\mathrm{C}_{139} \mathrm{H}_{99} \mathrm{Ir}_{3} \mathrm{O}_{27} \mathrm{P}_{8} \mathrm{Ru}_{6} \mathrm{~W}$ Calc.: C, 43.75; H, 2.61. IR ( $\left.v_{\mathrm{CO}}\right): 2055 \mathrm{~m}, 1996$ sh, 1979 vs, $1962 \mathrm{~s}, 1945 \mathrm{~m} \mathrm{~cm}^{-1}$. ${ }^{1} \mathrm{H}$ NMR $(\delta) 7.85-7.24(\mathrm{~m}$, 
$80 \mathrm{H}, \mathrm{Ph}), 4.13\left(\mathrm{t}, J_{\mathrm{HP}}=10 \mathrm{~Hz}, 4 \mathrm{H}, \mathrm{PCH}_{2} \mathrm{P}\right), 1.91(\mathrm{~s}, 15 \mathrm{H}$, $\left.\mathrm{C}_{5} \mathrm{Me}_{5}\right) .{ }^{31} \mathrm{P}$ NMR $(\delta) 16.2(\mathrm{~m}, 4 \mathrm{P}, \mathrm{dppm}), 12.2(\mathrm{~m}, 2 \mathrm{P}$, dppa-Ru), -6.7 (m, 2P, P-Ir). SI MS: $3816[\mathrm{M}]^{+}$.

\subsection{X-ray structural study of $R u_{3}(\mu-d p p m)(C O)_{9}\left(\eta^{1}-d p p a\right)$ (1)}

The crystal and refinement data for compound $\mathbf{1}$ are summarized in Table 1. A crystal suitable for the X-ray structural analysis was grown by liquid diffusion of $\mathrm{MeOH}$ into a $\mathrm{CH}_{2} \mathrm{Cl}_{2}$ solution at $276 \mathrm{~K}$. A single crystal was mounted on a fine glass capillary, and data collected on a Nonius Kappa CCD diffractometer at $200 \mathrm{~K}$ using graphite monochromated Mo $\mathrm{K} \alpha$ radiation $(\lambda=0.71073 \AA)$. The unit cell parameters were obtained by least-squares refinement [15] of 64891 reflections with $3 \leqslant \theta \leqslant 27^{\circ}$. The reduced data [15] were corrected for absorption using numerical methods [16] implemented from within MAXus [17]; equivalent reflections were merged. The structure was solved by heavy atom methods and expanded using Fourier techniques [18] within the software package MAXUS.

The crystallographic asymmetric unit consists of one molecule with all atoms in general positions. All nonhydrogen atoms were refined with anisotropic displacement parameters. $\mathrm{H}$ atoms attached to $\mathrm{C}$ atoms were included in idealized positions and ride on the atoms to which they are

\section{Table 1}

Crystal data and structure refinement details for $\mathrm{Ru}_{3}(\mu-\mathrm{dppm})(\mathrm{CO})_{9^{-}}$ ( $\eta^{1}$-dppa) (1)

\begin{tabular}{|c|c|}
\hline Empirical formula & $\mathrm{C}_{60} \mathrm{H}_{42} \mathrm{O}_{9} \mathrm{P}_{4} \mathrm{Ru}_{3}$ \\
\hline Formula weight & 1334.09 \\
\hline Crystal size (mm) & $0.55 \times 0.19 \times 0.06$ \\
\hline Colour, habit & Red, plate \\
\hline Crystal system & Triclinic \\
\hline Space group & $P \overline{1}$ \\
\hline$a(\AA)$ & $13.0679(2)$ \\
\hline$b(\AA)$ & $14.3773(2)$ \\
\hline$c(\AA)$ & $17.9416(3)$ \\
\hline$\alpha\left({ }^{\circ}\right)$ & $92.9927(11)$ \\
\hline$\beta\left(^{\circ}\right)$ & $109.7273(7)$ \\
\hline$\gamma\left({ }^{\circ}\right)$ & $115.1494(10)$ \\
\hline$V\left(\AA^{3}\right)$ & $2795.50(8)$ \\
\hline$Z$ & 2 \\
\hline$D_{\text {calc }}\left(\mathrm{g} \mathrm{cm}^{-3}\right)$ & 1.585 \\
\hline$\mu\left(\mathrm{mm}^{-1}\right)$ & 0.971 \\
\hline$\theta_{\max }\left({ }^{\circ}\right)$ & 27 \\
\hline$N_{\text {collected }}$ & 62725 \\
\hline$N_{\text {unique }}$ & 12784 \\
\hline$N_{\text {observed }}$ & $9006(I>3.00 \sigma(I))$ \\
\hline Absorption correction & Integration \\
\hline$T_{\min }, T_{\max }$ & $0.752,0.946$ \\
\hline No. of parameters & 685 \\
\hline$R^{\mathrm{a}}$ & 0.0307 \\
\hline$R_{\mathrm{w}}^{\mathrm{b}}$ & 0.0316 \\
\hline$S$ & 1.11 \\
\hline$(\Delta / \rho)_{\min }\left(\mathrm{e} \AA_{\circ}^{-3}\right)$ & -0.91 \\
\hline$(\Delta / \rho)_{\max }\left(\mathrm{e} \AA^{-3}\right)$ & 0.78 \\
\hline
\end{tabular}

${ }^{\mathrm{a}} R=\sum\left\|F_{\mathrm{o}}|-| F_{\mathrm{c}}\right\| / \sum\left|F_{\mathrm{o}}\right|$.

${ }^{\mathrm{b}} R_{\mathrm{w}}=\left[\left(\sum w\left(\left|F_{\mathrm{o}}\right|-\left|F_{\mathrm{c}}\right|\right)^{2} / \sum w F_{\mathrm{o}}^{2}\right)\right]^{1 / 2}$ bonded. The final cycles of matrix least-squares refinement were based on 9006 reflections and converged to $R=0.031$ and $R_{\mathrm{w}}=0.032$. The largest peaks in the final difference electron map are located near the $\mathrm{Ru}$ atoms.

\section{Results and discussion}

\subsection{X-ray structural study of $R u_{3}(\mu-d p p m)(C O)_{9}\left(\eta^{I}-d p p a\right)$ (1)}

One of the two monodentate dppa-ligated triruthenium clusters selected for the present study had been reported previously [13], but no structural data are extant. A single-crystal X-ray diffraction study of $\mathrm{Ru}_{3}(\mu$-dppm $)(\mathrm{CO})_{9-}$ ( $\eta^{1}$-dppa) (1) was carried out; an ORTEP diagram is shown in Fig. 1, while selected cell data and crystallographic structure acquisition and processing parameters are collected in Table 1, and selected bond lengths and angles are listed in Table 2. The structural study confirms the expected triangular triruthenium core with each ruthenium atom ligated by three carbonyl ligands and one phosphorus donor atom, the latter all in the equatorial plane defined by the metal atoms. The study also confirms the bidentate coordination of the dppm ligand and monodentate coordination of the dppa ligand. The cluster is electron precise, with 48 cluster valence electrons.

\subsection{Syntheses of $R u_{3}(C O)_{9}\left(\eta^{1}-d p p a\right)_{3}$ (2) and dppa-connected tri- and tetra-cluster species}

The tri-substituted cluster $\mathrm{Ru}_{3}(\mathrm{CO})_{9}\left(\eta^{1} \text {-dppa }\right)_{3}(2)$ was prepared in $30 \%$ yield from the reaction between $\mathrm{Ru}_{3}$ $(\mathrm{CO})_{9}(\mathrm{NCMe})_{3}$ and excess dppa (Scheme 1), and its

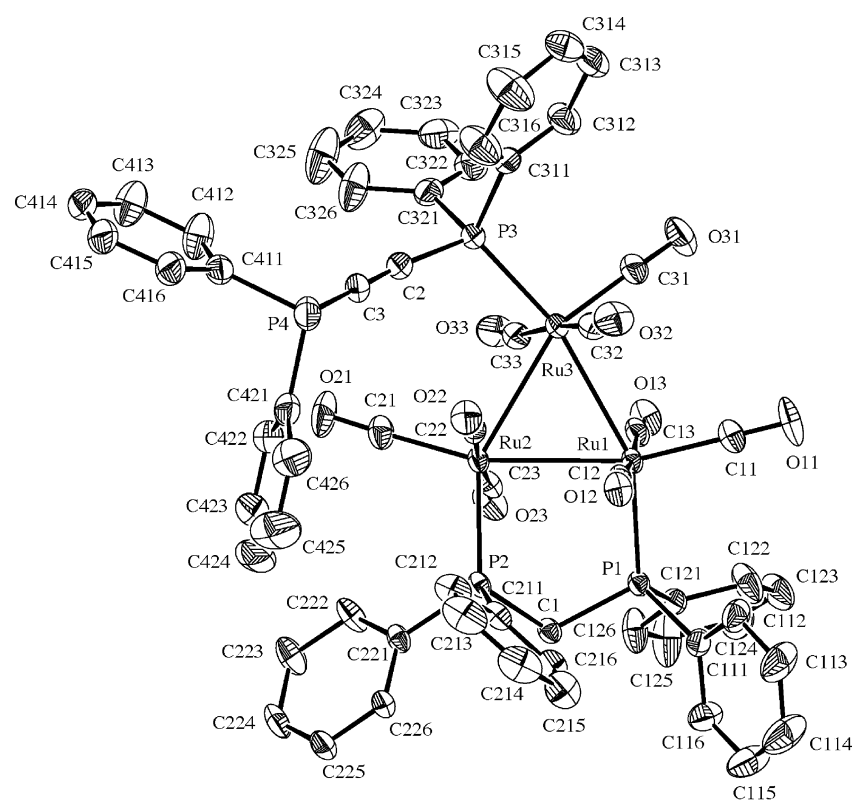

Fig. 1. ORTEP plot and atomic numbering scheme for $\mathrm{Ru}_{3^{-}}$ $(\mu$-dppm $)(\mathrm{CO})_{9}\left(\eta^{1}\right.$-dppa) (1). Displacement ellipsoids are at the $30 \%$ probability level. Hydrogen atoms have been omitted for clarity. 
Table 2

Selected bond lengths $(\AA)$ and angles $\left({ }^{\circ}\right)$ for $\mathrm{Ru}_{3}(\mu$-dppm $)(\mathrm{CO})_{9}\left(\eta^{1}\right.$-dppa $)$ (1)

\begin{tabular}{lclc}
\hline $\mathrm{Ru}(1)-\mathrm{Ru}(2)$ & $2.8229(3)$ & $\mathrm{Ru}(1)-\mathrm{Ru}(3)$ & $2.8329(4)$ \\
$\mathrm{Ru}(2)-\mathrm{Ru}(3)$ & $2.8530(3)$ & $\mathrm{Ru}(1)-\mathrm{P}(1)$ & $2.3206(8)$ \\
$\mathrm{Ru}(2)-\mathrm{P}(2)$ & $2.3366(8)$ & $\mathrm{Ru}(3)-\mathrm{P}(3)$ & $2.3176(9)$ \\
$\mathrm{Ru}(1)-\mathrm{C}(11)$ & $1.896(3)$ & $\mathrm{Ru}(1)-\mathrm{C}(12)$ & $1.932(3)$ \\
$\mathrm{Ru}(1)-\mathrm{C}(13)$ & $1.933(4)$ & $\mathrm{Ru}(2)-\mathrm{C}(21)$ & $1.885(4)$ \\
$\mathrm{Ru}(2)-\mathrm{C}(22)$ & $1.927(3)$ & $\mathrm{Ru}(2)-\mathrm{C}(23)$ & $1.928(3)$ \\
$\mathrm{Ru}(3)-\mathrm{C}(31)$ & $1.875(4)$ & $\mathrm{Ru}(3)-\mathrm{C}(32)$ & $1.948(4)$ \\
$\mathrm{Ru}(3)-\mathrm{C}(33)$ & $1.926(4)$ & & \\
$\mathrm{Ru}(1)-\mathrm{Ru}(2)-\mathrm{Ru}(3)$ & $59.879(8)$ & $\mathrm{Ru}(2)-\mathrm{Ru}(1)-\mathrm{Ru}(3)$ & $60.589(8)$ \\
$\mathrm{Ru}(2)-\mathrm{Ru}(3)-\mathrm{Ru}(1)$ & $59.532(8)$ & $\mathrm{Ru}(1)-\mathrm{Ru}(2)-\mathrm{P}(2)$ & $89.21(2)$ \\
$\mathrm{Ru}(2)-\mathrm{Ru}(1)-\mathrm{P}(1)$ & $93.30(2)$ & $\mathrm{Ru}(2)-\mathrm{Ru}(3)-\mathrm{P}(3)$ & $106.52(2)$ \\
$\mathrm{P}(1)-\mathrm{Ru}(1)-\mathrm{C}(11)$ & $102.11(12)$ & $\mathrm{P}(1)-\mathrm{Ru}(1)-\mathrm{C}(12)$ & $94.40(9)$ \\
$\mathrm{P}(1)-\mathrm{Ru}(1)-\mathrm{C}(13)$ & $91.95(10)$ & $\mathrm{P}(2)-\mathrm{Ru}(2)-\mathrm{C}(21)$ & $108.05(13)$ \\
$\mathrm{P}(2)-\mathrm{Ru}(2)-\mathrm{C}(22)$ & $94.78(10)$ & $\mathrm{P}(2)-\mathrm{Ru}(2)-\mathrm{C}(23)$ & $88.46(10)$ \\
$\mathrm{P}(3)-\mathrm{Ru}(3)-\mathrm{C}(31)$ & $100.91(12)$ & $\mathrm{P}(3)-\mathrm{Ru}(3)-\mathrm{C}(32)$ & $90.00(11)$ \\
$\mathrm{P}(3)-\mathrm{Ru}(3)-\mathrm{C}(33)$ & $91.58(11)$ & $\mathrm{Ru}(3)-\mathrm{Ru}(1)-\mathrm{C}(11)$ & $104.91(12)$ \\
$\mathrm{Ru}(3)-\mathrm{Ru}(1)-\mathrm{C}(12)$ & $92.65(9)$ & $\mathrm{Ru}(3)-\mathrm{Ru}(1)-\mathrm{C}(13)$ & $80.03(10)$ \\
$\mathrm{Ru}(3)-\mathrm{Ru}(2)-\mathrm{C}(21)$ & $104.68(12)$ & $\mathrm{Ru}(3)-\mathrm{Ru}(2)-\mathrm{C}(22)$ & $74.79(10)$ \\
$\mathrm{Ru}(3)-\mathrm{Ru}(2)-\mathrm{C}(23)$ & $100.21(9)$ & & \\
\hline
\end{tabular}

identity confirmed by IR, ${ }^{1} \mathrm{H}$ and ${ }^{31} \mathrm{P}$ NMR spectroscopy, electrospray mass spectrometry, and a satisfactory microanalysis. The solution IR spectrum shows the presence of terminal carbonyl ligands only. The ${ }^{31} \mathrm{P}$ NMR spectrum contains doublets in the ratio $1: 1$ at 7.6 and $-30.0 \mathrm{ppm}$, corresponding to the ligated and free phosphorus atoms of the dppa ligands, respectively. The mass spectrum contains a sodium adduct of the molecular ion, together with peaks corresponding to mono- and di-oxygen adducts of this ion.

Reacting this cluster with excess $\mathrm{Ru}_{3}(\mu$-dppm $)(\mathrm{CO})_{10}$ in the presence of trimethylamine $\mathrm{N}$-oxide afforded a mixture of products from which $\mathrm{Ru}_{3}(\mathrm{CO})_{9}\left\{\mathrm{PPh}_{2} \mathrm{C}_{2} \mathrm{PPh}_{2} \mathrm{Ru}_{3}-\right.$ $(\mu$-dppm $\left.)(\mathrm{CO})_{9}\right\}_{3}(3)$ was isolated in poor yield after chromatography (Scheme 2). In an attempt to improve the yield, an alternative approach was assayed; reaction of slightly more than three equivalents of $\mathrm{Ru}_{3}(\mu$-dppm)$(\mathrm{CO})_{9}\left(\eta^{1}\right.$-dppa) (1) with $\mathrm{Ru}_{3}(\mathrm{CO})_{9}(\mathrm{NCMe})_{3}$ afforded 3, but once again in poor yield following chromatography. The dodecanuclear dendrimer 3 was identified by IR, ${ }^{1} \mathrm{H}$ and ${ }^{31} \mathrm{P}$ NMR spectroscopy, and secondary ion mass spectrometry. The IR spectrum contains bands corresponding to terminal carbonyl ligands, while the ${ }^{1} \mathrm{H}$ NMR contains resonances in the anticipated ratio corresponding to phenyl
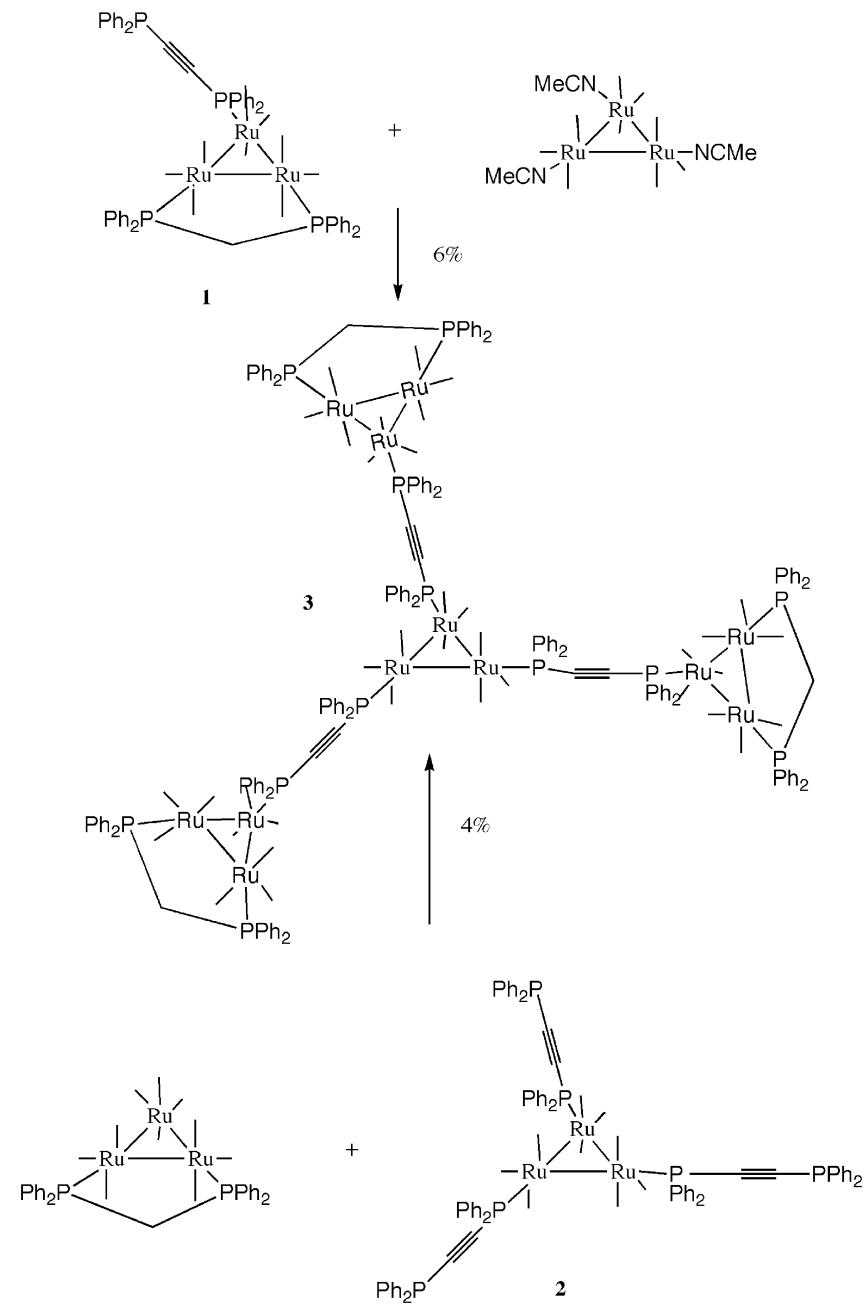

Scheme 2. Syntheses of $\mathbf{3}$.

and methylene groups. The ${ }^{31} \mathrm{P}$ NMR contains resonances in the ratio 2:1:1 arising from the dppm and dppa ligands, as expected. The mass spectrum contains a molecular ion.

Reaction of excess $\mathrm{Ru}_{3}(\mu$-dppm $)(\mathrm{CO})_{9}\left(\eta^{1}\right.$-dppa $)$ (1) with $\mathrm{WIr}_{3}(\mu-\mathrm{CO})_{3}(\mathrm{CO})_{8}\left(\eta-\mathrm{C}_{5} \mathrm{Me}_{5}\right)$ afforded $\mathrm{WIr}_{3}(\mathrm{CO})_{9^{-}}$ $\left\{\mathrm{PPh}_{2} \mathrm{C}_{2} \mathrm{PPh}_{2} \mathrm{Ru}_{3}(\mu \text {-dppm })(\mathrm{CO})_{9}\right\}_{2}\left(\eta-\mathrm{C}_{5} \mathrm{Me}_{5}\right)$ (4) in good yield (Scheme 3); no evidence for formation of the possible tris-product was found. The bis-product $\mathbf{4}$ was identified by IR, ${ }^{1} \mathrm{H}$ and ${ }^{31} \mathrm{P}$ NMR spectroscopy, mass spectrometry, and satisfactory microanalysis. As with the other products,

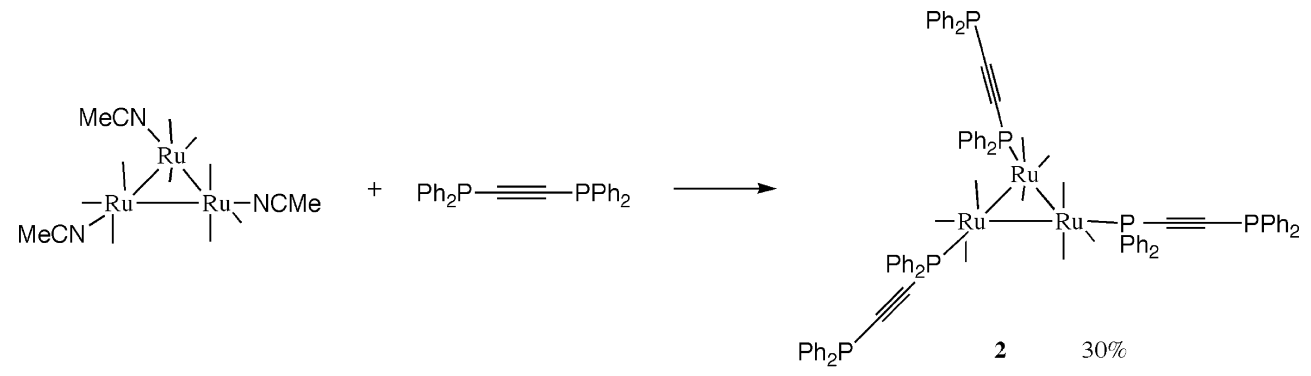

Scheme 1. Synthesis of $\mathbf{2}$. 
the IR contains terminal $v(\mathrm{CO})$ bands only, and the NMR spectra contain the expected resonances in the appropriate ratios; the mass spectrum contains a strong molecular ion.

\subsection{Discussion}

Phosphine derivatives of $\mathrm{Ru}_{3}(\mu-\mathrm{dppm})(\mathrm{CO})_{10}$ have been of long-standing interest $[19,20]$, although structural reports until recently were sparse [21]. Several crystallographic studies of clusters of general formula $\mathrm{Ru}_{3}-$ $(\mu$-dppm $)(\mathrm{CO})_{9}(\mathrm{~L}) \quad(\mathrm{L}=$ phosphine $)$ have now been reported [22,23], all with the same general ligand disposition as that of 1 reported herein. Structural trends for five examples have been analyzed by Koutsantonis and coworkers [23]. Significant differences in bond lengths and angles of the present cluster from the range of data in Koutsantonis' survey are short $\mathrm{Ru}(1)-\mathrm{Ru}(2)$ [2.8229(3) cf. 2.8343(9)-2.8756(3) ̊], $\mathrm{Ru}(2)-\mathrm{Ru}(3)$ [2.8530(3) cf. 2.8640 (4) $-2.9076(4) \AA]$ and $\mathrm{Ru}(3)-\mathrm{P}(3)$ [2.3176(9) cf. 2.340(2)2.397(2) $\AA$ ] vectors, large $\mathrm{P}(2)-\mathrm{Ru}(2)-\mathrm{C}(21) \quad[108.05(13)$ cf. 97.8(3)-101.1(2) ], $\mathrm{Ru}(3)-\mathrm{Ru}(1)-\mathrm{C}(11)$ [104.91(12) cf. 99.2(2)-102.6(2) ${ }^{\circ}$ and $\mathrm{Ru}(3)-\mathrm{Ru}(2)-\mathrm{C}(23)[100.21(9) \mathrm{cf}$. $\left.86.8(1)-99.0(2)^{\circ}\right]$ angles, and a small $\mathrm{Ru}(3)-\mathrm{Ru}(2)-\mathrm{C}(21)$ [104.68(12) cf. $\left.107.5(1)-118.0(3)^{\circ}\right]$ angle. Koutsantonis noted an increase in $\mathrm{Ru}(2)-\mathrm{Ru}(3)$ and $\mathrm{Ru}(3)-\mathrm{P}(3)$ upon increase in phosphine cone angle. The cone angle for
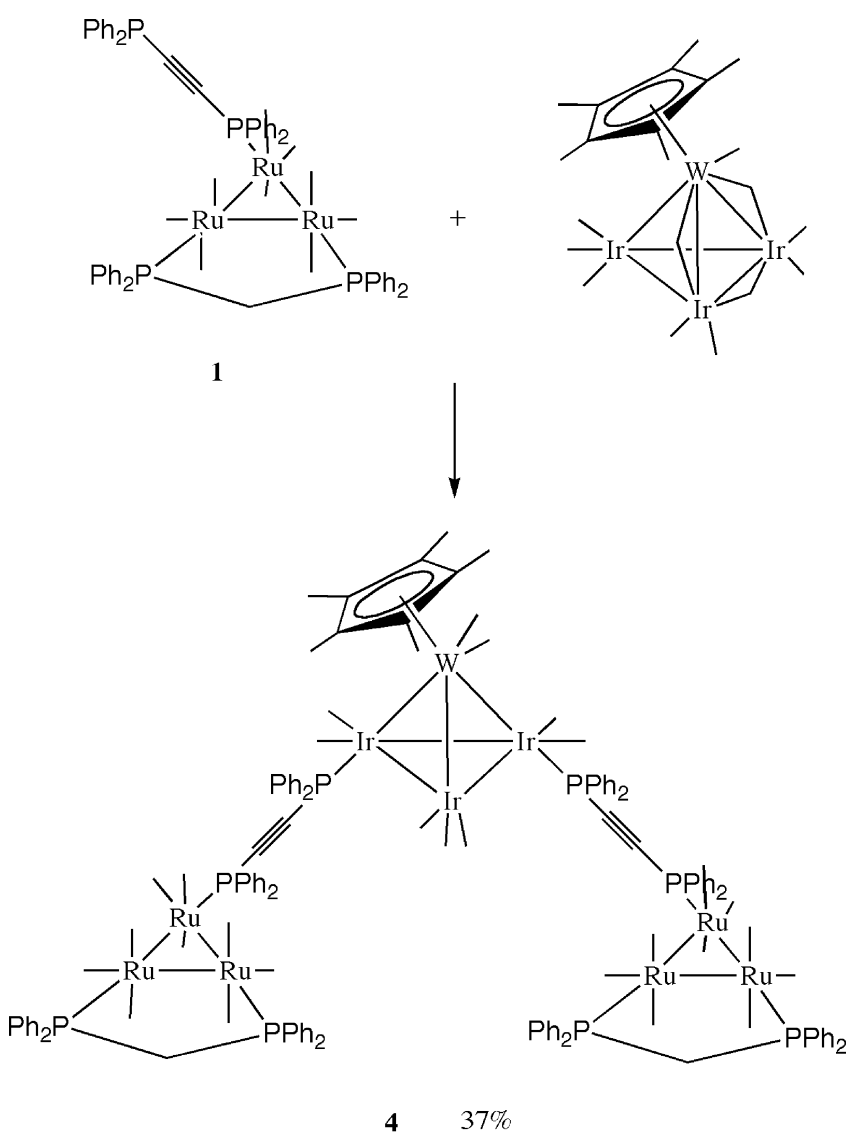

Scheme 3. Synthesis of 4. monodentate dppa has been suggested to be $145^{\circ}$ [24]. Notwithstanding the differences in crystallographic and calculated cone angles that have been noted [24], it might have been anticipated that on steric grounds the structural parameters would be similar to those observed for the triphenylphosphine adduct (cone angle for $\mathrm{PPh}_{3}: 145^{\circ}$ ). Dppa has increased $\pi$-acidity and decreased $\sigma$-donor strength compared to $\mathrm{PPh}_{3}$ [24], which should result in a weaker $\mathrm{Ru}(3)-\mathrm{P}(3)$ interaction [23], so the observed short $\mathrm{Ru}(3)-\mathrm{P}(3)$ linkage is puzzling. It is possible that these anomalous distances reflect the ability of the $\mathrm{P}(3) \mathrm{CCP}(4)$ substituent to be better accommodated within the arc $\mathrm{C}(21)-\mathrm{Ru}(2)-\mathrm{C}(22)$ than a phenyl ring of $\mathrm{PPh}_{3}$.

We have reported many examples of "simple" phosphine substitution at tetrahedral cyclopentadienyltungsten-triiridium clusters [14, and references therein], which all proceed with a change of carbonyl disposition from "all-terminal" to one incorporating a "plane-of-bridging-carbonyls"; this is the first example in this system for which phosphine substitution proceeds from the "plane-of-bridging-carbonyls" arrangement in the pentamethylcyclopentadienyltungstentriiridium precursor to the all-terminal carbonyl geometry of $\mathbf{4}$, an outcome almost certainly due to the steric constraints of the cluster-functionalized phosphine $\mathbf{1}$.

The linear bidentate diphosphine dppa has been employed in many previous studies to link cluster units to afford di-cluster molecules. Linking more than two clusters is much less explored. The low yields for the products reported in the present study have highlighted a possible lack of general utility of monodentate dppa-ligated cluster reagents for oligo-cluster construction.

\section{Acknowledgments}

We thank the Australian Research Council (ARC) for support of this work and Johnson-Matthey Technology Centre for the generous loan of ruthenium and iridium salts. M.G.H. is an ARC Australian Professorial Fellow.

\section{Appendix A. Supplementary data}

CCDC 631427 contains the supplementary crystallographic data for $\mathbf{1}$. These data can be obtained free of charge via http://www.ccdc.cam.ac.uk/conts/retrieving.html, or from the Cambridge Crystallographic Data Centre, 12 Union Road, Cambridge CB2 1EZ, UK; fax: (+44) 1223-336-033; or e-mail: deposit@ccdc.cam.ac.uk. Supplementary data associated with this article can be found, in the online version, at doi:10.1016/j.jorganchem. 2007.01.027.

\section{References}

[1] P. Braunstein, L.A. Oro, P.R. Raithby, Metal Clusters in Chemistry, Wiley-VCH, Weinheim, Germany, 1999.

[2] S. Aime, R. Gobetto, G. Jannon, D. Osella, J. Organomet. Chem. 309 (1986) C51. 
[3] See, for example (a) M.I. Bruce, M.L. Williams, J.M. Patrick, A.H. White, J. Chem. Soc., Dalton Trans. (1985) 1229;

(b) M.P. Cifuentes, M.G. Humphrey, A.C. Willis, J. Organomet. Chem. 513 (1996) 85.

[4] B.F.G. Johnson, K.M. Sanderson, D.S. Shephard, D. Ozkaya, W. Zhou, H. Ahmed, M.D.R. Thomas, L. Gladden, M. Mantle, Chem. Commun. (2000) 1317.

[5] N.T. Lucas, M.P. Cifuentes, L.T. Nguyen, M.G. Humphrey, J. Cluster Sci. 12 (2001) 201.

[6] N.T. Lucas, M.G. Humphrey, A.D. Rae, Macromolecules 34 (2001) 6188.

[7] N.T. Lucas, E.G.A. Notaras, M.P. Cifuentes, M.G. Humphrey, Organometallics 22 (2003) 284.

[8] N.T. Lucas, E.G.A. Notaras, S. Petrie, R. Stranger, M.G. Humphrey, Organometallics 22 (2003) 708.

[9] E.G.A. Notaras, N.T. Lucas, M.G. Humphrey, A.C. Willis, A.D. Rae, Organometallics 22 (2003) 3659.

[10] M.I. Bruce, B.K. Nicholson, M.L. Williams, Inorg. Synth. 26 (1989) 276.

[11] M.I. Bruce, B.K. Nicholson, M.L. Williams, Inorg. Synth. 28 (1990) 224.

[12] P. Grenouillet, C. De Bellefon, J. Organomet. Chem. 513 (1996) 155.

[13] M.I. Bruce, P.A. Humphrey, B.W. Skelton, A.H. White, J. Organomet. Chem. 539 (1997) 141.

[14] A.J. Usher, G.T. Dalton, N.T. Lucas, S.M. Waterman, S. Petrie, R. Stranger, M.G. Humphrey, A.C. Willis, J. Organomet. Chem. 689 (2004) 50 .
[15] Z. Otwinowski, W. Minor, in: C.W. Carter Jr., R.M. Sweet (Eds.), Methods in Enzymology, Academic Press, New York, 1997, p. 307.

[16] P. Coppens, in: F.R. Ahmed, S.R. Hall, C.P. Huber (Eds.), Crystallographic Computing, Munksgaard, Copenhagen, 1970, p. 255.

[17] S. Mackay, C.J. Gilmore, C. Edwards, N. Stewart, K. Shankland, MAXUS: computer program for the solution and refinement of crystal structures, Nonius, The Netherlands, MacScience, Japan, and The University of Glasgow, UK, 1999.

[18] P.T. Beurskens, G. Admiraal, G. Beurskens, W.P. Bosman, R. de Gelder, R. Israel, J.M.M. Smits, The DIRDIF-96 Program System, Technical Report of the Crystallography Laboratory, University of Nijmegen, The Netherlands, 1996.

[19] D.F. Foster, J. Harrison, B.S. Nicholls, A.K. Smith, J. Organomet. Chem. 248 (1983) C29.

[20] M.I. Bruce, P.A. Humphrey, R.J. Surynt, E.R.T. Tiekink, Aust. J. Chem. 47 (1994) 477.

[21] O. bin Shawkataly, K. Ramalingam, D.M. Ashari, H.-K. Fun, I.A. Razak, Acta Crystallogr., Sect. C 54 (1998) 329.

[22] M.I. Bruce, O. Kühl, B.W. Skelton, A.H. White, Aust. J. Chem. 52 (1999) 705.

[23] A.A. Torabi, A.S. Humphreys, G.A. Koutsantonis, B.W. Skelton, A.H. White, J. Organomet. Chem. 655 (2002) 227.

[24] E. Stulz, M. Maure, N. Feeder, S.J. Teat, Y.-F. Ng, A.D. Bond, S.L. Darling, J.K.M. Sanders, Inorg. Chem. 41 (2002) 5255. 